\title{
ANTHRACNOSE CROWN ROT DISEASE OF STRAWBERRY PLANTS IN EGYPT AND ITS CONTROL
}

\author{
M.A. Awad, M.Z. El-Shanawany and M.A. Gad Allah \\ Agric. Botany Dept., Faculty of Agriculture, Menoufia Univ., Shibin El-Kom, Egypt.
}

Received: Aug. 27, 2018

Accepted: Sep. 1, 2018

\begin{abstract}
Isolation and identification of fungal pathogens were purified and identified as: Colletotrichum acutatum, Alternaria tenius and others. C. acutatum and $A$. tenius were the most frequent fungi that isolated from samples of strawberry plant materials which collected from the different locations in both seasons 2013/2014 and 2014/2015. Susceptible strawberry cultivar Florida was highly susceptible one where infection reached to $100 \%$ infection by Colletotrichum acutatum isolate. 2. Also, Alternaria tenius was pathogenic to c..v Florida, but came in the second rank in pathogenicity tests. The most effective bioagent was $T$. viride. Also, treating strawberry plants with different concentrations of organic acids affected greatly $C$. acutatum and A.tenius Ascorbic acid at 200 ppm concentration is the best effective concentration in controlling both pathogens in vitro .. Gall extract affected greatly the growth of. both pathogens in all daily records from 1-6 days, followed by both plant extracts Mustard and Clove.. Two fungicides (recommended for up ground diseases of strawberry plants); i.e., Bellis 38\% WG (with three doses; $0.4 \mathrm{~g} / \mathrm{L} ., 0.8 \mathrm{~g} / \mathrm{L}$. and $1.6 \mathrm{~g} / \mathrm{L}$.) and Amistar 25\% SC (with three doses; $2.5 \mathrm{ml} / \mathrm{l}$., $5 \mathrm{ml} / \mathrm{l}$. and $10 \mathrm{ml} / \mathrm{l}$.) were used in this experiments. . Complete inhibition of fungal growth was noticed in both high concentration of the tested fungicides and little growth was happened in the low concentration of Bellis and Amistar. A. tenius was revealed as less tolerant to fungicides than C. acutatum. All tested treatments against both pathogens in vitro under laboratory conditions were applied in vivo under field conditions on strawberry plants cv. Florida to investigate their effects on plants under natural infection in field. All growth characteristics of different parts of strawberry cv. Florida like leaves number, lateral branches, flower number, green fruits, colored fruits, TSS\% and fruits weight were affected as a result of infection with pathogens and treated with different chemical, biological and agricultural treatments, there were great variations among all applied treatments in this respect, The best treatments were fungicides, followed by gall extract and un-mulched control treatment comparing with other treatment and control treatment (un-treated), All disease symptomson strawberry cv. Florida were calculated on plant leaves, flower parts, vegetative fruit characteristics. Black spot, irregular spot, black margin, petiole lesions and dead leaf were calculated during the period ranged between 3-15 days at $15^{\text {th }}-30^{\text {th }}$ March, 2015. Both chemical fungicides (Bellis 38\% WG and Amistar 25\% SC) controlled completely the leaf infection symptoms, followed by Galls $10 \%$. Treating plants with Kocide 2000, Ascorbic acid 5\% and T viride protected plants with various degrees of infection.
\end{abstract}

Key words: Strawberry, Anthracnose, Crown rot, Colletotrichum acutatum, Alternaria tenius, Control.

\section{INTRODUCTION}

The crown rot disease is one of the most important diseases limiting the cultivation and yield of strawberry
(Fragaria $x$ ananassa Duch.) in many countries. Major species that cause strawberry crown rot and anthracnose are Colletotrichum acutatum Simonds, $C$. 
fragariac Brooks and C. gloeosporioides (Penz) Penz. Sacc. (Howard et al., 1992; Smith, 1986 and Smith and Black, 1990). Debode et al., (2015) stated that Colletotrichum acutatum (spp. complex), has become a trouble some problem in strawberry production worldwide.) Debode et al., (2015) recorded crown rot (Phytophthora cactorum) and leaf diseases (Colletotrichum acutatum) in strawberry, in Finland production fields. Poling (2008) reported that colletotrichum acutatum has become an even more serious threat to strawberry plant in major strawberry growing areas of North America. This highly virulent pathogen causes fruit rot, crown rot, root rot and Fesions on petioles and stolons. Embabv et al., (2010) published the first report of colletutrichum acutatum and $C$. gloeosporioides causing anthracnose diseases on strawberry (Fragaria $x$ ananassa) fields in Kalubia and Ismailia governorate in Egypt. Arroyo et al, (2009) recorded that strawberry anthracnose, caused by colletotrichum acutatum, is one of the most important diseases of this crop in south western Spain. They added that lesions can occur on all parts of the plant but anthracnose crown rot is especially severe leading to wilt and death of plants. Freeman (2008) mentioned that Colletotrichum spp. are bored-rang pathogens, meaning that species can infect a single host and a single species can infect deserve hosts. Anthracnose is one of the major fungal diseases of strawberry occurring worldwide. In Israel, the disease is caused primarily by the species $C$. acutatum. The pathogen is most destructive when it causes root necrosis and crown rot, which usually kill the plants in nurseries and transplants in the field. Detpode et al., (2015) reported that anthracnose, caused by Colletotrichum acutatum (species complex), has become a troublesome problem in strawberry production worldwide. Baroncelli et al,
(2015) illustrated that Colletotrichum acutatum isolated from plant materials from different geographic areas in Europe.

Grellet - Bournonville, et al., (2012) examined the participation of the salicylic acid (SA) signaling pathway involved in the response of Fragariae $x$ ananasa cv. Pajaro plants to Colletotrichum spp. pathogens. Results obtained supports the hypothesis that strawberry plants activate a SA mediated defense mechanisms that is effective against a casual agent of anthracnose. Awad and Al-Shennawy (2015) reported that in vivo experiments, all plant extracts with different concentrations which applied as dipping treatment decreased gray mould rot disease severity of strawberry fruits especially Galls, Clove and cinnamon extracts. Abril et al., (2009) studied that the steroidal saponin from cayenne pepper, CAY-1 was tested as potential fungicide in detached leaf assays and field trials. Efficacy of CAY-1 against strawberry anthracnose was compared to the commercial fungicide azoxystrobin. CAY-1 reduced the growth of several fungal pathogens in lab assays and prevented anthracnose development in detached-leaf assays, but it did not control foliar or fruit-rot diseases of strawberry in field trials. Porras et al., (2003) studied that they evaluated the effect of non-chemical alternatives to control colletotrichum crown rot and anthracnose in strawberry plants. Azoxystorbin, pyraclostrobin, or thiophanate-metlyl applications should be applied when weather conditions are highly favourable for disease development and the activity of contact fungicides such as captan or thiram might be comparomised. Daughvish et al., (2009) inoculated daughter plants of strawberry (fragariae $x$ ananassa) with Colletotrichum acutatum. Plants were subsequently dipped in fungicide solutions. Fungicide treatments reduced 
plant dieback by up to $92 \%$ in fruit production fields.

This work aimed to throw the light on the iportance. of anthracnose crown rot disease in Beheira governorate in Egypt through isolation and identifecation the causal pathogens- Also, controlling the disease using some biotic and abiotic agents.

\section{MATERIALS AND METHODS}

This work was concerned with crowns causal organisms and different methods of control these important diseases and minimizing strawberry fruit losses. All laboratory trials were carried out at Plant Pathology Research laboratories, Agricultural Botany Department, Faculty of Agriculture, Menoufia University, Shebin El-Kom, Egypt, while the field trials were conducted at Badr District Behaira governorate, West Nile Delta, Egypt.

Isolation of causal organisms fungi: Samples of diseased strawberry plants showing crown rot symptoms were collected for determination the occurrence of fungi associated with diseased plants. They were obtained occasionally over a two-year period of 2014 and 2015 seasons, from open Fields. Samples were obtained from four fields of four farms where plants were suffered from crown rot disease symptoms. The infected crown rot, short stems, roots, runners were used for pathogens isolation.

Isolation and identification of biological agents: The Dilution Plate Method (DPM) was used for the isolation of Biological agent fungi. Soil and rhizosphere samples were taken from strawberry fields by uprooting the infected plants with great care to obtain most of the intact root system. Trichoderma Selective Medium (TSM) was used also for isolation of
Trichoderma species isolates from soil (Elad et al., 1981).

Purification and Identification of the isolated fungi: Purification of the isolated fungi was carried out using hyphal tip and lor single spore techniques according to Dhingra and Sinclair (1985) methods. The developed fungal colonies were identified using the morphologic al and macroscopically characteristics according to Barnett and Hunter (1972), Domsch et al. (1980). Cultures were multiplied and maintained on PDA slants and kept at $5^{\circ} \mathrm{C}$ for further studies. On the other hand, isolates of Trichoderma spp. as well as Bacillus spp. obtained from the rhizosphere of strawberry were identified after growing them on $20 \%$ malt extract agar which they were incubated for two days at $25^{\circ} \mathrm{C}$ according to Rifai (1969) and Bissett (1991). Stock cultures were maintained on PDA slants in a refrigerator at $5^{\circ} \mathrm{C}$ and were subculture on fresh medium every 6-8 weeks.

Pathogenicity tests: Transplants representing strawberry commercial cultivar namely Florida kindly provided by Strawberry Improvement Center, Faculty of Agriculture, Ain-Shams University during the progress of the present investigation. Apparently healthy transplants were carefully selected. The inoculum was mixed with sterile water with the desired rate $50 \mathrm{~g} / \mathrm{l}$ L.water and checked on shaker and spore concentrations were adjusted at the rate of $1 \times 10^{6} / \mathrm{ml}$. The plants were inoculated by spraying the spore suspensions where the concentrations were adjusted at the rate of $1 \times 10^{6} \mathrm{spore} / \mathrm{ml}$ ) individually on each plant. In check experiment, equal amounts sterile water were sprayed on each plant. Each of both selected isolated fungi (Colletotrichum acutatum and Alternaria tenius) was represented by one isolate according to its highest frequency, obtained from a certain 
localities, during isolation trials. Disease incidence assessment in different experiments was carried out through percentage of infection (infection \%). The percentage of infection was calculated according to the following formula:

Infection \% = Number of infected plants I Total number of plans

Control of anthracnose crown rot pathogens in vitro

The selective two pathogenic fungi; Colletotrichum acutatum and Alternaria tenius were subjected to some laboratory tests to study their effects on both pathogens in Petri dishes under laboratory conditions to select the more effective treatments for applying under field conditions

Antagonistic activities of Trichoderma spp. in dual culture against Colletotrichum acutatum and Alternaria tenius were studied in Petri dishes according to the method described by Fokkema (1973) and Zahra (1990).

Organic acids control: Organic acids i.e., Ascorbic acid, Salicylic acid and Oxalic acid at different concentrations $(12.5,25,50,100$ and 200 ppm) were used for controlling crown rot disease on strawberry plants using more virulent pathogens (C. acutatuum and $A$. tenius).

Plant extracts control: Plant water extracts of three plants i.e. Gall (Quercus infectoria), Mustard (Brassica alba) and clove (Eugenia coryophyllata) in three concentrations of each (i.e. 2.5, 5 and $10 \%$ ) were tested against both virulent pathogens.

Effect of fungicides and chemical compound on strawberry crown rot pathogens in vitro: Two fungicides (recommended for up ground diseases on strawberry plants) i.e.: Bellis 38\% WG with three doses $(0.4 \mathrm{~g} / \mathrm{L}, 0.8 \mathrm{~g} / \mathrm{L}$ and 1.6 g/L). Amistar 25\% SC with 3 doses (2.5 $\mathrm{ml} / \mathrm{L}$., $5 \mathrm{ml} / \mathrm{L}$ and $10 \mathrm{ml} / \mathrm{L}$ ). Also, two chemical compounds, each of them was treated with three doses for con trolling both crown rot pathogens, i.e.: Kocide 2000 53.8\% WP with 3 doses (0.9 g/L., 1.8 g/L. and 3.6 g/Litre). Potssium citrate $5 \%$ solution with three doses $(2.5 \mathrm{ml} / \mathrm{L}$., 5 $\mathrm{ml} / \mathrm{L}$. and $10 \mathrm{ml} /$ Liter).

Field program experiments in vivo: Strawberry cv. Florida was selected for field experiments i.e. biological control, systemic and contact fungicides, in addition to mineral salts, antioxidants, agricultural practices (irrigation, fertilization and non-mulch plants). This cultiver growing in Egypt in commercial scale because its stability in fruit production and well known as genetic stability and resulted from tissue culture propagation techniques. All above mentioned field trials were applied at Om Saber Village - Badr district, Behaira Governorate-under field conditions. The field experiment was started at $1^{\text {st }}$ march, 2014 to $30^{\text {th }}$ march, 2014. This represents the best time of high productivity for this selected cultiver and appropriate temperature for growth and spread of both selected pathogens of crown rot in strawberry fields (Colletotrichum acutatum and Alternaria tenius). The nursery soil was prepared by adding the recommended treatments/ feddan. With regard to the field soil of strawberry plantation, it prepared as follows: Animal manure $30 \mathrm{~m}^{3} /$ feddan, Poultary manure $10 \mathrm{~m}^{3} \mathrm{l}$ feddan, Agricultural calcium sulphate $500 \mathrm{~kg} /$ feddan, El Mowffer fertile $125 \mathrm{kgl}$ feddan, Agricultural sulpher $125 \mathrm{~kg} /$ feddan, Super phosphate calcium $15.5 \%, 500 \mathrm{~kg} /$ feddan.

All fertilizers were well spreaded and soil plowed orthogonal four times, and then fermented with sprays with 8 hours/ day for three days. Lines widith divided into $1.25 \mathrm{~m}$ with intervals $50 \mathrm{~cm}$, then sterilization was done and washing of soil was done for three days, and stomp 
extra (pendamethalin) pre plantation was sprayed with 1 Literl 100 Liter for controlling the grasses. The irrigation system was done using 2 plastic tabes 16 $\mathrm{mm}$ (GR 30) for every trac $(40 \mathrm{~cm}$ between) plus tube for mist irrigation $3 \mathrm{~m}$ x $3 \mathrm{~m}$ with 20 L/hours. Florida cultiver was planted at August, 15th, 2014 with spaces $25 \times 25 \mathrm{~cm}$. At flowering stage, the fertilization was done as follows: $5 \mathbf{~ k g}$ ammonium nitrate $+6 \mathrm{~kg}$ potassium sulphate $+1 \mathrm{~kg}$ phosphoric acid $+1 \mathrm{~kg}$ Magnisium sulphate $+250 \mathrm{~g}$ element mixture for five days -5 Liter green $+1 / 2$ $\mathrm{kg}$ Amino acid + $3 \mathrm{~kg}$ Calcium nitrate for one dosel weekly. Re-transplant another transplants instead of the dead one a new transplants grown in plastic pots with the same age. Cutting of purlins and pre-flowering flowers was done daily and the grasses were removed also.

Covering of plants with thin layer of non-colored plastic 90 micron with $\mathbf{1 1 0}$ $\mathrm{kg} /$ feddan. The field trials were planned by select four wide lines for each strawberry variety separately and must be in the middle of the field to avoid any external effects on plant growth during the time of experiments. Strawberry plants were planted on the wide line at 1.25 meter width, and the distance between plants $25 \times 25 \mathrm{~cm}$, at the meantime.

The following treatments were applied on strawberry plants (cv.Florida) as follows: Systemic fungicides: Amistar (Azoxystrobin) 25\% $\quad$ SC-50 $\mathrm{ml} / 100 \mathrm{~L}$. Water. Bellis (Bosclid 25.2\% w/w + pyrachlorstrobin $12.8 \%$ w/w)- $80 \mathrm{~g} / 100 \mathrm{~L}$. Water. Contact fungicides: Kocide 2000 (Cupper hydroxide)- 180 g/ 100 L. Water. Mineral salts: Potassium citrate 5\% -1 Literl $100 \mathrm{~L}$ Water. Organic acids : Ascorbic acid 5\%. Biological control agents: Trichoderma viride. Plant extract: Gall extract $10 \%$ l Liter.

Experimental plants were treated twice on the plants in each compound separately for the first time before 14 days of infection - the second before 7 days of zero time of disease estimation under natural infection under field conditions. The control treatments were treated by spraying with water at the mean time of the field treatment, and the plants were examined for disease infection at the same time.

\section{EXPERIMENTAL RESULTS:}

Isolation and identification of fungal pathogens causing strawberry crown rot and anthracnose disease: Data presented in Table (1) illustrate that 898 plant materials out of 2400 strawberry plant materials were clear diseased by crown rot and anthracnose diseases with typical symptoms in both seasons 2014 and 2015. Number of diseased samples was higher in the second season 2015 (454 samples) in comparing with the first season 2014 (444 diseased samples). Also, data show that means of crown rot and anthracnose diseases incidence of strawberry at different localities ranged between 19 to $51 \%$ during 2015 season with average $37.0 \%$ while, during 2015 season means of crown rot disease incidence ranged between 28 to $50 \%$ with average $37.83 \%$. Isolation was made on PDA medium yielded a group pathogenic fungi, either singly or in combinations groups. The isolated fungi were purified and identified as: Colletotrichum acutatum, Colletotrichum spp, Fusarium oxysporum, Alternaria tenius, Alternaria alternata, Alternaria solani, Trichoderma spp and others as shown in Table (1). Data presented in Table (1) indicate that Colletotrichum acutatum, was the most frequent fungus that isolated from samples of strawberry plant materials which collected from the different locations in both seasons $37.68 \%$ in $2013 / 2014$ season, while it was $37.61 \%$ in 2014/ 2015 season, followed by Alternaria tenius $(18.36 \%$ and $22.48 \%)$ in the same 
M.A. Awad, et al.,

seasons, respectively. Other isolated pathogens were isolated in both seasons with low frequencies, in comparing with the most frequent two pathogens. The least frequent fungus was Alternaria solani $(10.15 \%)$ in the first season, while Colletotrichum fragareae was the least frequent one $(7.34 \%)$ in the second season. Also, the biological control agents were isolated from diseased strawberry materials that collected from the different locations at the four villages belonging to Badr district in Behaira governorate, i.e. Trichoderma harzianum, $T$. hamatum and $T$. viride .

\section{Pathogenicity tests:}

Four isolates from the most frequent two pathogens, i.e. Colletotrichum acutatum and Alternaria tenius, each isolate representing one village and isolated from diseased materials that collected from different strawberry growing areas in Bader district, Behaira governorate were tested for their virulence on three commercial strawberry cultivars under controlled conditions in greenhouses. The selected strawberry cultivar was Florida. Data in Table (2) illustrate that, susceptible strawberry cultivar FLORIDA was highly susceptible one and infection reached to $100 \%$ infection by Colletotrichum acutatum isolate No. 2 that isolated from Sokhna village with clear crown rot symptoms, followed by isolate No. 3 (96.15\%). Also, Alternaria tenius was pathogenic to Florida cultivar, but came in the second rank in pathogenicity tests. The most percentage of crown rot disease symptoms was $72.32 \%$ on plants infected by isolate No. 3 (that isolated from Nabil El-Wakkad village), followed by $\mathbf{7 0 . 1 5 \%}$ on Florida plants infected by isolate No. 2 (Sokhna village).

Table (1): Frequency of isolated fungi from diseased crowns and roots of strawberry plants -samples collected from four villages during 2013/2014 and 2014/2015 seasons in some localities in Behaira governorate of West Nile Delta of Egypt.

\begin{tabular}{|c|c|c|c|c|c|c|c|c|c|c|c|c|}
\hline \multirow[b]{3}{*}{ Isolated Fungi } & \multicolumn{12}{|c|}{ Season - villages - frequency (\%) } \\
\hline & \multicolumn{6}{|c|}{ 2013-2014 } & \multicolumn{6}{|c|}{ 2014-2015 } \\
\hline & 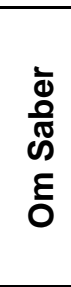 & 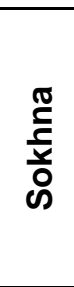 & 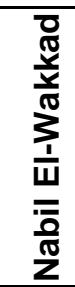 & 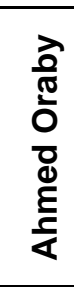 & 죰 & o & 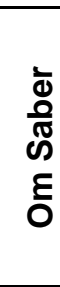 & 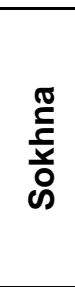 & 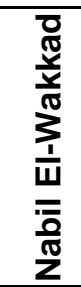 & 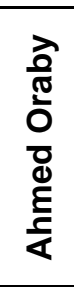 & $\begin{array}{l}\bar{\pi} \\
\text { 0 } \\
-1\end{array}$ & o \\
\hline $\begin{array}{l}\text { Fusarium } \\
\text { oxysporum }\end{array}$ & 3 & 5 & 2 & 3 & 13 & 6.28 & 2 & 7 & 6 & 3 & 18 & 8.26 \\
\hline $\begin{array}{l}\text { Cholletotrichum } \\
\text { acutatum }\end{array}$ & 23 & 16 & 22 & 17 & 78 & 37.68 & 21 & 23 & 17 & 21 & 82 & 37.61 \\
\hline $\begin{array}{l}\text { Cholletotrichum } \\
\text { fragareae }\end{array}$ & 15 & 6 & 6 & 2 & 29 & 14.01 & 7 & 2 & 2 & 5 & 16 & 7.34 \\
\hline Alternaria alternata & 4 & 6 & 3 & 9 & 22 & 10.63 & 3 & 6 & 7 & 7 & 23 & 10.56 \\
\hline Alternaria tenius & 10 & 9 & 11 & 8 & 38 & 18.36 & 13 & 11 & 9 & 16 & 49 & 22.48 \\
\hline Alternaria solani & 7 & 3 & 7 & 4 & 21 & 10.15 & 5 & 8 & 6 & 2 & 21 & 9.63 \\
\hline Trichoderma spp & 1 & 2 & 0 & 3 & 6 & 2.89 & 0 & 3 & 4 & 2 & 9 & 4.13 \\
\hline Total & 63 & 47 & 51 & 46 & 207 & & 51 & 60 & 51 & 26 & 218 & \\
\hline
\end{tabular}


Table (2): Virulence of two strawberry pathogens on strawberry cv florida under greenhouse conditions.

\begin{tabular}{|c|c|c|c|c|c|}
\hline Fungus & Isolate & Location & Symptoms & Infection \% & Healthy \% \\
\hline \multirow{4}{*}{$\begin{array}{l}\text { Colletotrichum } \\
\text { acutatum }\end{array}$} & 1 & Om Saber & Crown rot & 91.40 & 8.60 \\
\hline & 2 & Sokhna & Crown rot & 100.00 & 00.00 \\
\hline & 3 & N. Wakkad & Crown rot & 96.15 & 3.85 \\
\hline & 4 & Ahmed Oraby & Crown rot & 88.20 & 11.80 \\
\hline \multirow{4}{*}{ Alternaria tenius } & 1 & Om Saber & Crown rot & 36.73 & 63.27 \\
\hline & 2 & Sokhna & Crown rot & 70.15 & 29.85 \\
\hline & 3 & N. Wakkad & Crown rot & 72.32 & 27.68 \\
\hline & 4 & Ahmed Oraby & Crown rot & 40.00 & 60.00 \\
\hline Control & & & & 00.00 & 100.00 \\
\hline
\end{tabular}

As for Florida strawberry cultivar, data in Table (2) show that this cultivar was reacted with $100.00 \%$ crown rot symptoms when infected by isolate No. 3 of C. acutatum , followed by $93.33 \%$ on strawberry plants infected by isolate No. 2 of the sane pathogenic fungus. Other two isolates (isolate $1 \& 4$ ) were highly pathogenic also and reacted by 90.00 and 89.13\% respectively. Alternaria tenius also infected Florida cultivar with low percentages of infection in comparing to C. acutatum. The maximum \% of infection was $73.32 \%$, followed by $70.30 \%$ when plant infected by isolates No. 3 \& 4, respectively.

Physiological studies: The selective two pathogenic fungi; Colletotrichum acutatum and Alternaria tenius were subjected to some laboratory tests to study their effects on both pathogens in Petri dishes under laboratory conditions to select the more effective treatments for applying on plants under field conditions

Antagonistic activities of Trichoderma spp. in dual culture against
Colletotrichum acutatum and Alternaria tenius were studied in Petri dishes. The effect of different isolates of bioagents i.e., Trichoderma harzianu and T. viridi on radial growth and the percentage of growth inhibition against Colletotrichum acutatum and Alternaria tenius, the causal pathogens of crown rot and anthracnose of strawberry plants was studied in vitro. The above mentioned isolates of bioagents were tested individually against both isolates of fungal pathogens. Clear differences in radial growth of the different tested pathogens under stress of bioagents. Also, there were clear differences between the pathogenic isolates in dual cultures and the control treatments which included the pathogen isolates without biocontrol agents. The least linear growth of $C$. acutatum isolate that affected by $T$. viride isolate $(26.0 \mathrm{~mm})$, followed by $T$. harzianum isolate (33.0 $\mathrm{mm}$ ), three tested biological agents acted with Alternaria tenius with the same trend of C. acutatum. All tested isolates of bioagent affected linear growth of the pathogen isolates of ( $A$. tenius) in dual 
cultures. The most effective bioagent was $T$. viride, while the least growth inhibition against $A$. tenius was $31.1 \%$. Trichhoderma viride isolate only grow over growth of $A$. tenius with $2.8 \mathrm{~mm}$, while $T$. harzianum inhibition zone between growth of $A$. tenius and its growth $(2.3 \mathrm{~mm})$. Generally, Trichoderma viride isolate was effective against both pathogenic isolates.

Organic acid control: Three antioxidants i.e., Ascorbic acid, Salicylic acid and Oxalic acid were used in this study. Each organic acid with five concentrations i.e., 12.5, 25, 50, 100 and $200 \mathrm{ppm}$ were used for controlling anthracnose and crown rot diseases on strawberry plants using more virulent fungal pathogens (Colletotrichum acutatum and Alternaria tenius). The fungus $C$. acutatum was affected by treated organic acids with various concentrations. Ascorbic acid was greatly affected the fungal growth in comparing to both other organic acids.. From noticed results of organic acids and their effects on fungal growth, it was clear that increasing of organic acids concentration from $12.5 \mathrm{ppm}$ to $200 \mathrm{ppm}$, gradually decrease the fungal growth in vitro.These results indicate that ascorbic acid at $\mathbf{2 0 0}$ ppm concentration is the best effective concentration in controlling $C$. acutatum in vitro. As for Alternaria tenius pathogen, the same trend of results with C. acutatum was noticed also with $A$. tenius, but the means of linear growth were less in $A$. tenius in comparing to these means with $C$. acutatum. It is also clear that a ascorbic acid with 200 ppm concentration was noticed as the best treatment for controlling the fungal growth of $A$. tenius in vitro.

Plant extracts control: All tested aqueous plant extracts affected greatly the growth of Colletotrichum acutatum and Alternaria tenius isolates on media mixed with adjusted concentrations of each of the three tested plant extracts. Plant aqueous extracts were Gall (Quercus infectoria), Mustard (Brassica alba) and Clove (Eugenia coryophyllata) in three concentrations of each i.e., 2.5, 5 and $10 \%$ were added individually to PDA medium in Petri dished. Gall extract affected greatly the growth of $C$. acutatum in all daily records from 1-6 days, followed by both plant extracts Mustard and Clove. Plant extracts affected greatly the growth of $A$. tenius comparing to the fungus $C$. acutatum. Gall extract was the best treatment in inhibition the fungal growth in vitro.

Chemical control of anthracnose and crown rot pathogens invitro: Two fungicides (recommended for up ground diseases of strawberry plants); i.e. Bellis 38\% WG (with three doses; $0.4 \mathrm{~g} / \mathrm{L}$., 0.8 g/L. and $1.6 \mathrm{~g} / \mathrm{L}$.) and Amistar 25\% SC (with three doses; $2.5 \mathrm{ml} / \mathrm{l} ., 5 \mathrm{ml} / \mathrm{l}$. and 10 $\mathrm{ml} / \mathrm{l}$.) were used in this experiments by adding these fungicides individually to Czapeck's medium in Petri dishes with the above mentioned concentrations. Also, in these experiments, two chemical compounds; i.e. kocide $2000,53.8 \%$ WP (with three doses; $0.9 \mathrm{~g} / \mathrm{L}$., $1.8 \mathrm{~g} / \mathrm{L}$. and $3.6 \mathrm{~g} / \mathrm{L}$.) and potassium citrate $5 \%$ solution (with three doses $2.5 \mathrm{ml} / \mathrm{l}$., $5 \mathrm{ml} / \mathrm{l}$. and $10 \mathrm{ml} / \mathrm{l}$.).

All tested treatments decreased the pathogen growth on to medium in vitro in comparing to control treatment. In this respect, Collectotrichum acutatum growth on medium was greatly affected as a result of treated fungicides where it disappeared in most plates containing two concentrations of the fungicide Bellis $38 \%$ WG i.e. $0.8 \mathrm{~g} / \mathrm{l}$. and $1.6 \mathrm{~g} / \mathrm{l}$. at all the 6 days of growth measuring, while the growth of the same fungus was recorded few growth rates between 2 to 6 days of the experiment time (6 days). Mean time, Amestar 25\% SC recorded the maximum effect on $C$. acutatum growth. Complete inhibition of fungal growth was recorded 
by the applied concentrations, except the $5^{\text {th }}$ and $6^{\text {th }}$ day in the case of the least concentration of this fungicide $(25 \mathrm{ml} / \mathrm{l}$.$) ,$ while the growth was inhibited completely by treatment with 5 and 10 $\mathrm{ml} / \mathrm{l}$. Regarding the effect of both recommended two fungicides, Amistar $25 \%$ SC recorded the best effect on fungal growth (mean diameter of fungal growth in Petri dishes). It recorded 0.56 $\mathrm{mm}$ after incubation for 6 days on 26士 $2^{\circ} \mathrm{C}$, followed by Bellis $35 \%$ WG. Data indicate also that the chemical compound copper hydroxide 53\% WP (Kocide 2000) was affected the growth of C. acutatum in Petri dishes, and a complete inhibition of fungal growth was achieved by the concentrations of $1.8 \mathrm{~g} / \mathrm{l}$. and $3.6 \mathrm{~g} / \mathrm{l}$. , Mean while the least concentration ( $0.9 \mathrm{~g} / \mathrm{l}$.) was affected the pathogen growth to values similar to those recorded with the first concentration of Bellis $(0.4 \mathrm{~g} / \mathrm{L})$. The mean diameter of fungal growth was 3.94 $\mathrm{mm}$ that recorded by the three treated concentrations.

As for the effect of potassium citrate, the three treated concentrations 2.5, 5 and $10 \mathrm{ml} / \mathrm{l}$., affected the growth of $C$. acutatum, but with low effect in comparing with both tested recommended fungicides and the copper hydroxide $53 \%$ WP. The pathogen Alternaria tenius also was affected by fungicides and chemical compounds treatment in Petri dished under laboratory condition. The same trend of results was similar on this pathogen as revealed with $C$. acutatum but with some differences between them. Complete inhibition of fungal growth was noticed in both high concentration of the tested fungicides, and little growth was happened in the low concentration of Bellis and Amistar. A. tenius revealed as less tolerant to fungicides than $C$. acutatum.
Field program experiments in vivo:

The infections and symptoms were examined on plants as leaf infection symptoms, flower parts symptoms, fruit infection symptoms and the vegetative and fruit characteristics of strawberry cultivars after 30 days from planting under field conditions during four weeks post plantation $\left(15^{\text {th }}\right.$, March to $30^{\text {th }}$, March, 2015). With regard to leaf infection under field condition. Data indicate that, both used fungicides; Bellis and Amistar stopped leaf infection on cv. Florida. Also, Gall $10 \%$ plant extract also, controlled leaf infection under field conditions. All rest treatments, were varied in their effects on leaf infections, where kocide 2000 controlled black spot and irregular spot at the 4 examination, periods but black margin, petioles lesion and dead leaf were noticed at the last examination period at $\mathbf{4 5}$ days from trial start ,on the other hand, Ascorbic acid $5 \%$ had no effect on leaf infection while black spot and irregular spot were noticed at 7, 11 and 15 days of examination. Also, black margin and petiole lesion were recorded at $\mathbf{1 1}$ and $\mathbf{1 5}$ days examination while dead leaf was noticed at last period of examination at 45 days from trial start. However, Trichoderma viride had moderate effect, leaf infection symptoms, black spot were noticed at 45 days post inoculation; petiole lesion and dead leaf, while irregular spot and black margin symptoms were not noticed in the case of $T$. viride. Regarding to agricultural practices; irrigation with 1/2 amount, 1/2 fertilization ratio, non mulch and potassium citrate, it was clear that they affected the infection symptoms with clear differences among them where the symptoms almost appeared in the fourth examination period on one plant or two plants of the five tested plants without stable trend. As for the control plants, the leaf infection symptoms were not noticed 
Regarding the control plants without treatments, the infection symptoms leaves on leaves were noticed at 7,11 and 15 days post plantation under field conditions as shown in Tables (3-7).

The infection symptoms were disappeared on Florida plants sprayed by Bellis 38\% WG and Amistar 25\% SC fungicides as well as Galls $10 \%$ plant extract. Kocide 2000, Ascorbic acid 5\% and $T$. viride were reacted with various levels of flower parts infection, whereas flower center infection symptoms were higher in the treatments of Ascorbic acid and Trichoderma viride with 3.3 and 5 and 2, 2 and 3 in 7, 11 and 15 days post plantation, respectively. The cultural treatments were varied in their effects on flower parts infection. The maximum flower death was happened in 1/2 fertilization, without mulch and potassium citrate (5 plants) treatments in comparison with control treatment. As for infected fruits on cv. Florida, both used fungicides controlled completely fruit infections. Also Gall $10 \%$ was the best effective treatment in controlling fruit petioles and green fruits, while, only one plant was infected on coloured fruits in this case. All rest treatments gave variable effect in controlling the fruit parts infection. The infected fruits in control treatment and/or cultural practices were noticed as high levels of infection on all fruit parts. Fruits petioles, green fruits and colored fruits were infected within 15 days plantation under field conditions.

All growth characteristics of different parts of strawberry cv. Florida like leaves number, lateral branches, flower number, green fruits, colored fruits, TSS\% and fruits weight were affected as a result of infection with pathogens and treated with different chemical, biological and agricultural treatments, there were great variations among all applied treatments in this respect, the best treatments were fungicides, followed by gall extract and un-mulched control treatment comparing with other treatment and control treatment (un-treated). With regard to disease symptoms on Florida strawberry, all disease symptoms were calculated on plant leaves, flower parts, fruits and vegetative in addition to fruit characteristics. Black spot, irregular spot, black margin, petiole lesions and dead leaf were calculated during the period ranged between 3-15 days at $15^{\text {th }}$ $30^{\text {th }}$ March, 2015. Both chemical fungicides (Bellis 38\% WG and Amistar $25 \%$ SC) were controlled completely the leaf infection symptoms, followed by Galls $10 \%$. Treating plants with Kocide 2000, Ascorbic acid 5\% and Trichoderma viride protected plants with various degrees of infection.

Table (3): Growth characteristics of healthy FLORIDA cultivated strawberry variety at March, 2015.

\begin{tabular}{|c|c|c|c|c|c|c|c|c|c|c|c|c|c|c|c|c|}
\hline $\begin{array}{c}\text { Date of } \\
\text { investiqation }\end{array}$ & \multicolumn{8}{|c|}{$1^{\text {st }}$ March } & \multicolumn{8}{|c|}{$14^{\text {th }}$ March } \\
\hline 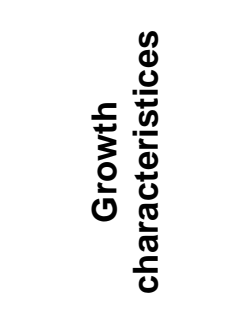 & 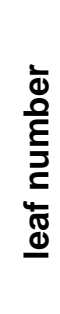 & 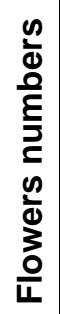 & 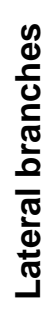 & $\begin{array}{l}\stackrel{n}{\frac{N}{J}} \\
\stackrel{2}{\underline{2}} \\
\frac{c}{d} \\
\frac{d}{0}\end{array}$ & $\begin{array}{l}0 \\
\stackrel{0}{2} \\
\frac{2}{2} \\
0 \\
\frac{d}{0} \\
\frac{0}{0} \\
0\end{array}$ & 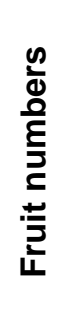 & $\begin{array}{l}\text { ১ீ } \\
\text { ம் } \\
\text { ம் }\end{array}$ & 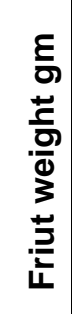 & 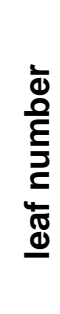 & 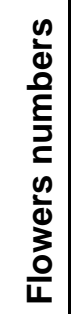 & 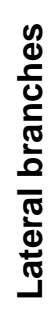 & 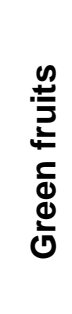 & 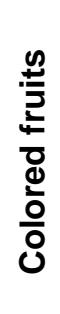 & 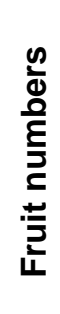 & $\begin{array}{l}\text { ঠீ } \\
\text { ஸे } \\
\text { ஸे } \\
\vdash\end{array}$ & 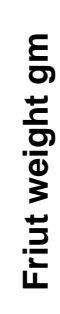 \\
\hline Florida & 17 & 9 & 3 & 9 & 5 & 5 & 8.1 & 40 & 20 & 11 & 3 & 11 & 8 & 8 & 8.3 & 35 \\
\hline
\end{tabular}


Anthracnose crown rot disease of strawberry plants in Egypt and its .........

Table 4 
M.A. Awad, et al.,

Table 5 
Table (6): Characteristics of strawberry Fruits cv. Florida under field conditions at 3-15 days from starting during March 2015.

\begin{tabular}{|l|c|c|c|c|c|c|c|c|c|c|c|c|}
\hline $\begin{array}{l}\text { No. of infected Day } \\
\text { of examination }\end{array}$ & \multicolumn{4}{|c|}{ Fruits Petiol } & \multicolumn{4}{c|}{ Green Fruits } & \multicolumn{3}{c|}{ Coloured Fruits } \\
\hline Treatment & 3 & 7 & 11 & 15 & 3 & 7 & 11 & 15 & 3 & 7 & 11 & 15 \\
\hline Bellis 38\% WG & 0 & 0 & 0 & 0 & 0 & 0 & 0 & 0 & 0 & 0 & 0 & 1 \\
\hline Amistar 25\% sc & 0 & 0 & 0 & 0 & 0 & 0 & 0 & 0 & 0 & 0 & 0 & 1 \\
\hline Kocide 2000 & 0 & 0 & 0 & 1 & 0 & 0 & 0 & 1 & 0 & 0 & 0 & 3 \\
\hline Ascorbic acid 5\% & 0 & 0 & 0 & 1 & 0 & 1 & 1 & 2 & 0 & 0 & 0 & 3 \\
\hline Trichoderma viride & 0 & 0 & 0 & 1 & 0 & 0 & 0 & 2 & 0 & 0 & 0 & 2 \\
\hline Galls 10\% & 0 & 0 & 0 & 0 & 0 & 0 & 0 & 0 & 0 & 0 & 0 & 1 \\
\hline 1/2 Irrigation Water & 0 & 0 & 0 & 1 & 0 & 0 & 1 & 2 & 0 & 0 & 0 & 3 \\
\hline 1/2 Fertilization-ratio & 0 & 0 & 0 & 0 & 0 & 0 & 0 & 1 & 0 & 0 & 0 & 1 \\
\hline With out mulching & 0 & 0 & 0 & 1 & 0 & 0 & 1 & 2 & 0 & 0 & 1 & 3 \\
\hline Potassium citrate & 0 & 0 & 0 & 2 & 0 & 0 & 1 & 3 & 0 & 2 & 4 & 5 \\
\hline Control & 0 & 0 & 0 & 0 & 0 & 0 & 0 & 0 & 0 & 0 & 0 & 0 \\
\hline Total number & 0 & 0 & 0 & 7 & 0 & 1 & 4 & 13 & 0 & 4 & 11 & 23 \\
\hline Control (un-treated) & 0 & 2 & 4 & 5 & 0 & 1 & 3 & 4 & 0 & 3 & 4 & 5 \\
\hline
\end{tabular}

Table (7): Growth characteristics of strawberry cv. Florida under field condutuin at 3-15 days post trial starting (from $15^{\text {th }}$ to $30^{\text {th }}$, March 2015).

\begin{tabular}{|l|c|c|c|c|c|c|c|c|c|c|c|c|c|c|}
\hline Average & \multicolumn{2}{|c|}{$\begin{array}{c}\text { Leaves } \\
\text { number }\end{array}$} & \multicolumn{2}{c|}{$\begin{array}{c}\text { Lateral } \\
\text { branches }\end{array}$} & \multicolumn{2}{c|}{$\begin{array}{c}\text { Flower } \\
\text { number }\end{array}$} & \multicolumn{2}{c|}{$\begin{array}{l}\text { Green } \\
\text { fruits }\end{array}$} & \multicolumn{2}{c|}{$\begin{array}{c}\text { Colored } \\
\text { fruits }\end{array}$} & \multicolumn{2}{c|}{ TSS\% } & \multicolumn{2}{c|}{$\begin{array}{c}\text { Fruits } \\
\text { weight g }\end{array}$} \\
\hline Week & 3 & 15 & 3 & 15 & 3 & 15 & 3 & 15 & 3 & 15 & 3 & 15 & 3 & 15 \\
\hline Bellis 38\% WG & 19 & 23 & 4 & 4 & 12 & 15 & 7 & 7 & 6 & 7 & 8.1 & 8.2 & 30 & 30 \\
\hline Amistar 25\% sc & 20 & 22 & 4 & 4 & 13 & 16 & 6 & 7 & 5 & 7 & 8.0 & 8.1 & 29 & 31 \\
\hline Kocide 2000 & 18 & 20 & 4 & 4 & 8 & 8 & 6 & 5 & 4 & 6 & 7.7 & 7.9 & 26 & 27 \\
\hline Ascorbic acid 5\% & 15 & 17 & 3 & 3 & 6 & 5 & 3 & 3 & 2 & 3 & 8.1 & 8.0 & 20 & 21 \\
\hline Trichoderma viride & 19 & 19 & 4 & 4 & 4 & 4 & 3 & 4 & 4 & 4 & 8.3 & 8.1 & 23 & 26 \\
\hline Galls 10\% & 20 & 20 & 4 & 4 & 11 & 13 & 6 & 6 & 7 & 7 & 7.9 & 7.6 & 28 & 29 \\
\hline 1/2 Irrigation Water & 14 & 16 & 3 & 3 & 6 & 7 & 3 & 3 & 4 & 6 & 8.0 & 7.9 & 22 & 26 \\
\hline $\begin{array}{l}1 / 2 \\
\text { ratio Fertilization- }\end{array}$ & 11 & 10 & 2 & 3 & 6 & 8 & 3 & 3 & 2 & 2 & 8.1 & 7.8 & 20 & 20 \\
\hline With out mulching & 11 & 9 & 3 & 3 & 4 & 8 & 4 & 4 & 2 & 3 & 7.2 & 7.4 & 21 & 20 \\
\hline Potassium citrate & 18 & 19 & 4 & 4 & 11 & 12 & 6 & 6 & 6 & 6 & 0.8 & 7.9 & 25 & 29 \\
\hline Control & 20 & 24 & 4 & 4 & 15 & 19 & 7 & 9 & 7 & 7 & 8.3 & 8.6 & 31 & 29 \\
\hline Total number & 8 & 6 & 4 & 4 & 3 & 3 & 2 & 2 & 2 & 1 & 6.8 & 6.1 & 20 & 18 \\
\hline Control(un-treated) & & & & & & & & & & & & & & \\
\hline
\end{tabular}




\section{DISCUSSION}

Crown rot diseases are one of the most important disease that affecting and limiting the fruit production of strawberry plantations in many parts of the world including Egypt. (Abada, 1986; Mostafa et al., 1992; Fahim et al., 1994 and Ragab Seham, 2007). Strawberry crown samples showing typical rot symptoms were collected from four villages belonging to Badr district in Behaira governorate from strawberry plants of different cultivars grown in commercial fields, during two successive seasons (2013/ 2014 and 2014/ 2015). The causal pathogens were isolated from diseased samples. 898 plant materials out of 2400 strawberry collected plant materials were clear diseased by crown rot disease with typical symptoms in both studied seasons. Strawberry crown samples showing typical rot symptoms were collected from four villages belonging to Badr district in Behaira governorate from strawberry plants of different cultivars grown in commercial fields, during two successive seasons (2013/ 2014 and 2014/ 2015). The causal pathogens were isolated from diseased samples. 898 plant materials out of 2400 strawberry collected plant materials were clear diseased by crown rot disease with typical symptoms in both studied seasons.

Number of diseased samples was higher in 2015 comparing with the first season; 2014;. The percentage of crown rot disease incidence of strawberry plants at different localities were lesser during 2014 season than the second season 2015. Colletotrichum acutatum, Colletotrichum musa, Fusarium oxysporum, Alternaria tenius, $A$. alternate, $A$. solani, Trichoderma spp. and others were isolated and identified from strawberry diseased samples.
These results are confirmed by the findings of Smith (1986); Howard et al., (1992) and Smith and Black (1990). Debode et al., (2015) mentioned that Colletotrichum acutatum caused some problem of strawberry production worldwide. Colletotrichum acutatum were isolated from diseased crowns in many countries from cold-stored strawberry plants used as planting material in several European countries (Debode et al., (2015); Calleja et al., (2013) in UK since 1982 on plants originating from USA; Van Hemelrijck et al., (2010) isolated $C$. acutatum from strawberry in Belgian fields; Parikka and Tuvinen (2014) recorded Phytophthora cactorum and Colletotrichum acutatum in strawberry plants in Finland production fields. Many investigators were recorded this disease on strawberry plants in many states in America, i.e., Smith (2008), Smith (2013), Polling (2008), Lewers et al., (2007), Howard et al., (1992). Also, this causal organism (C. acutatum) was recorded in south western Spain (Arroyo et al., 2009); in western Australia \& in Israel (Freeman, 2008) in Japan (Tanaka et al.,2002 and Passos, 2002), in different countries of Europe (Debode et al., 2015 and Baroncelli et al., 2015). In Latin America, the pathogen was recorded in Argentina (Salazar et al., 2007), in Brazil (Dias et al., 2005). The pathogen was recorded in many counties worldwide, where strawberry production and cultivation, i.e., in China (Wu et al., 2013), in many arab countries (El-Gali, 2008) in Libia. Moreover, in Egypt by many investigators. Colletotrichum acutatum was the most frequent fungus that isolated from samples of diseased strawberry materials which collected from different locations in both studied seasons (2013/2014 and 2014/2015) followed by Alternaria tenius in the same seasons, respectively. Other isolated 
pathogens were isolated in low frequencies, in comparing to the most frequent two mentioned pathogens. These results were in accordance with those obtained by Embaby et al., (2010), in Egypt, Smith (2008), Howard et al., (1990), Freeman (2008), Debode et al., (2015), Salazar et al., (2007) and Baroncelli et al., (2015). All tested isolates of both chosen pathogens were pathogenic to theall plants of the tested cultivar but with various degrees of infection. These results are in accordance with those resulted by Lilja et al., (1998), Freeman (2008), Smith (2008), Arroyo et al., (2009) and Hemelrijck et al., (2010).

In control treatments of fungal growth in Petri dishes under laboratory conditions, all tested aqueous plant extracts affected greatly the growth of Colletotrichum acutatum and Alternaria tenius isolates on media mixed with adjusted concentrations of each of the three tested plant extracts. Gall (Quercus infectoria), Mustard (Brassica alba) and Clove (Eugenia coryophyllata) plant materials were involved in these studies. Gall extract inhibited fungal growth of the pathogen C. acutatum with highly effect, in comparing to both other tested plant extracts (Mustard and Clove). The same effect were agreed with the second pathogen $A$. tenius also, but the effect of the three plant extracts was effective on Alternaria tenius than on C. acutatum . Gall, Mustard and clove were affected greatly the linear growth of $A$. tenius. These results are in accordance with those obtained by Abril et al., (2009), Xing et al., (2010) and others. Ascorbic acid affected greatly the fungus growth, gradually by increasing the concentration from 12.5 to $200 \mathrm{ppm}$. Comparing to the other two organic acids with $C$. acutatum and $A$. tenius. These results are in agreement with Grellet-Bournville et al.,
(2012)). Trichoderma viride was the most effective bioagent against both $C$. acutatum and $A$. tenius where the least linear growth of the pathogens as well as the maximum growth reduction. Both Trichoderma spp., grew over the pathogens grown in Petri dishes. The least effective bioagent was $B$. Subtilis. These results are agreement with those obtained by Porras et al., (2003), Chalfoun et al., (2011), Nam et al., (2014) and Harender (2014). The superior effect was by both fungicides, i.e. Amistar and Bellis, respectively, followed by Kocide 2000, and Potassium citrate, respectively. These results were confirmed by the results of Smith and Black (1993), Santos et al., (2002), Daughvish et al., (2009), Mackenzie et al., (2009) and Smith et al., (2013). Concerning infections of both pathogens on strawberry plants under field conditions. The most effective treatment was Amistar 25\%, followed by Bellis $38 \%$ WG. Meanwhile, Galls $10 \%$ plant extract was the best non chemical substance in controlling the infection of C. acutatum and $A$. tenius on strawberry plants under field conditions.

\section{REFERENCES}

Abada, K.A. (1986). Pathological studies on root rot of strawberry. Ph.D. Thesis, Fac. of Agric., Cairo Univ. 218 pp.

Abril, M., K.J. Curry, B.J. Smith, A.J. Delucca, S. Boue and D.E. Wedge (2009). Greenhouse and field evalution of the natural saponin CAY-1 for control of several strawberry diseases. International $J$. of Fruit Sience, 9 (3): 211-220.

Arroyo, F.T., Santos B. Delos, F. Romero, J. Moreno, P. Daza and J. Torreblanca (2009). Characterization of infection and colonization of strawberry crowns by Colletotrichum acutatum . Acta Horticulturee, 842: 231-234. 
Awad, H.M. and M.Z. Al-Shennawy (2015). Efficacy of some plant extracts on Botrytis cinerea, the causal

Barnett, H.L. and B.B. Hunter (1972). Illustrated genera of imperfect fungi. Minnesota Burges Publ. Co.241 p.

Baroncelli, R., S. Sarrocco, A. Zapparata, S. Tavarini, L.G. Angelini and C. Vannacci (2015). Characterization and epidemiology of Colletotrichum acutatum sensu lato (C. chrysanthemi) causing Carthamus tenctorius anthranose. Plant pathology. 64 (2): 376-384.

Bissett, J. (1991). A revision of the genus Trichoderma. II. Interagenetic classification. Can. J. Bot. 69: 23572372.

Calleja, E.J., B. Ilbery, N.J. Spence and P.R. Mills (2013). The effectiveness of phytosanitary controls in preventing the entry of Colletotrichum acutatum in the UK strawberry sector. Plant Pathology, 62 (2): 266-278.

Chalfoun, N.R., A.P. Castagnaro and J.C. Diaz Ricci (2011). Induced resistance activated by a culture filtrate derived from an avirulent pathogen as a mechanism of biological control of anthracnose in strawberry. Biological control, 58 (3): 319-329.

Daughvish, O., H. Su and W.D. Gubler (2009). Pre plant fungicide dips of strawberry transplants to control anthracnose caused by Colletotrichum acutatum in California. Hort Technology, 19 (2): 317-323.

Debode, J., W. Van Hemelrijck, X.M. Xu, M. Maes, $P$. Creemers and $K$. Heungens (2015). Latent entry and spread of Colletotrichum acutatum (Species complex) in strawberry fields. Plant pathology. 64 (2): 385-395.

Dhingra, O.D. and J.B. Sinclair (1985). Basic Plant Pathology Methods, CRC Press. Boca Raton, F.L.
Dias, M.S.C., R.da S. Canuto, L.O. Santos and R.N. Martins (2005). Diseases of strawberry, Informe Agropecuario, 26 (228): 40-43.

Domsch, K.H., W. Games and T.H. Anderson (1980). Compendium of soil fungi. Vol. I. London, Academic Press, 859 pp.

Elad, Y., Y. E. Hadar, I. Chet and Y. Henis (1981). Biological control of Rhizoctonia solani by Trichoderma harziamum in carnation. Plant Dis., 65: 675-677.

El-Gali, Z.I. (2008). A study of strawberry leaf spot in Jabel El-Akhdar Area, Libya. Arab. Jorunal of Plant Protection, 26 (2): 160-162.

Embaby, E.M., M.E. Ragab, Kh.A. Al Doug Doug, R. Ahmed, A. Zveibil, M. Maymon and S. Freeman (2010). First report of Colletotrichum acutatum and c. gloeosporioides causing anthracnose diseases on strawberry in Egypt. Plant Pathology. 59 (4): 808.

Fahim, M.M., M.F. Attia, A.K. Okasha and K.A. Abada (1994). Control of strawberry root rot disease by soil fumigation. Egyptian $J$ of phytopathology, 22 (1): 1-15.

Fokkema, N.J. (1973). The role of saprophytic fungi in antagonism against Dreschslera sorokniama (Helminthosporium sativum) on agar plates and on rye leaves with pollen. Physiol. Plant Pathol., 3: 195-205.

Freeman, S. (2008). Mamagement, survival strategies, and host range of Colletotrichum acutatum on strawberry. Hort Science, 43 (1): 66-68.

Grellet-Bournonville, C.F., M.G. Martinez, A.P. Castagnaro and J.C. Diaz-Ricci (2012). Temporal accumulation of salicylic acid activates the defense response against Colletotrichum in strawberry. Plant Physiology and Biochemistry. 54: 10-16. 
Harender Raj. (2014). Integration of soil solarization with soil amendments, botanicals and microbial pesticides for the management of soil -borne diseases of strawberry. Indian Phytopathology., 67 (3): 238-242.

Howard, C.M., C.K. Chandler and E.E. Abregts (1990). The strawberry into the $21^{\text {st }}$ century: Proceedings of the third North American strawberry. Conference, Houston, Texas. 1991: 219-220.

Howard, C.M., J.I. Maas, C.K. Chandler and E.E. Albergts (1992). Anthracnose of strawberry caused by the Colletotrichum complex in Florida, Plant Dis. 76: 976-981.

Lewers, K.S., W.W. Turechek, S.C. Hokanson, J.L. Maas, J.F. Hancock, S. Serca and B.J. Smith (2007). Evaluation of elite native strawberry germplasm for resistance to anthracnose crown rot disease caused by colletotrichum species. Jour. of American Soc., for Horticultural Scie., 132 (6): 842-849.

Lilja, A., R. Kajalainen, P. Parikka, K. Kammioverta and H. Nuorteva (1998). Pathogenicity and genetic variation of Phytophthora cactorum from silver birch and strawberry. European Jour. of Plant Pathology, 104 (6): 529-535.

Mackenzie, S.J., J.C. Martely and N.A. Peres (2009). Curative and protectant activity of fungicides for control of crown rot strawberry caused by Colletotrichum gloeosporioides. Plant Disease, 93 (8): 815-820.

Mostafa, A.M., Y.S. Khafagi, W.M. Assal and H.A. Mohamed (1992). Integrated control for root rot and with diseases of strawberry. Egypt. J. Appl. Sci., 7 (9): 277-291.

Nam, M.H., H.S. Kim, H.D. Lee, K.S. Whang and H.G. Kim (2014). Biological control of anthracnose crown rot in strawberry using Bacillus velezensis
NSB-1. Acta Horticulturae. 1049: 685688.

Polling, E.B. (2008). Anthracnose on strawberry: its etiology, epidemiology and pathology together with management strategies for strawberry nurseries: Introduction to the workshop. Hort. Science, 43 (1): 59-65.

Porras, M., C. Barrau, B. Santos, C. Blanco, F.T. Arroyo and F. Romero (2003). Combined effect of Trichoderma applications and soil solarization on colletotrichum crown rot in strawberry plants. Bulletin OILB/SPOR, 26 (10): 113-114.

Porras, M., C. Barrau, B. Santos, C. Blanco, F.T. Arroyo and F. Romero (2003). Combined effect of Trichoderma applications and soil solarization on colletotrichum crown rot in strawberry plants. Bulletin OILB/SPOR, 26 (10): 113-114.

Ragab, Seham S.M. (2007). Studies on root rot and wilt diseases of strawberry in Egypt. Ph.D. Thesis, Fac., of Agric., Menoufia Univ., 175 pp.

Rifai, M.A. (1969). A revision of the genus Trichoderma Commonwelth Mycol. Inst. Mycol. Pap. 116. 56 pp.

Salazar, S.M., A.P. Castagnaro, M.E. Arias, N. Chalifoun, U. Tonello and J.C. Diaz Ricci (2007). Induction of a defense response in strawberry mediated by an avirulent strain of Colletotrichum. European J. of plant Pathology, 117 (2): 109-122.

Santos Garcia de Paredes, B. delos; Romero Munos, F. (2002). Effect of different fungicides in the control of Cholletotrichum acutatum, causal agent of anthracnose crown rot in strawberry plants. Crop Protection. 21 (1): 11-15.

Smith, B.J. (1986). First report of Colletotrichum acutatum on strawberry in the united states. Plant Dis. 70: 1074. 
Smith, B.J. (2008). Epidemiology and pathology of strawberry anthracnose: a North American perspective. Hort Science, 43 (1): 69-73.

Smith, B.J. (2013). Strawberry anthracnose progress toward control through science. International Journal of Fruit Sciene. 13 (1/2): 91-102.

Smith, B.J. and L.L. Black (1990). Morpgological, cultural and pathogenic variation among Colletotrichum species from strawberry. Plant Dis. 74: 69-76.

Van Hemelrijck, W., J. Debode, K. Heungens, M. Maes and P. Creemers (2010). Phenotypic and genetic characterization of Colletotrichum isolates from Belgian strawberry fields. Palnt Pathology. 59 (5): 853861.
Wu Xiang, JI Muxing, C. Honzhou, Y. Jing Hui, Y. KeBing, W. Lili, Z. Cheng Gang and W. Jian (2013). Pathogen identification and germicide screening for strawberry anthracnose in Jurong area. Jiangsu J. of Agric., Scie., 29 (6): 1510-1518.

Xing, Y., Li. Xihong, Xu. Qinglian, J. Yun and Lu. Yaqung (2010). Antifungal activities of cinnamon oil against Rhizopus nigricans, Aspergillus flavus and Penicillium expansum in vitro and in vivo fruit test. Internation J. of Food Sci. and the Fachnology. 45 (9): 18371842.

Zahra, A.M. (1990). Studies on wilt disease of sesame (Sesamum indicum L.) in upper Egypt. Ph.D. Thesis, Fac. of Agric, Assiut Univ.

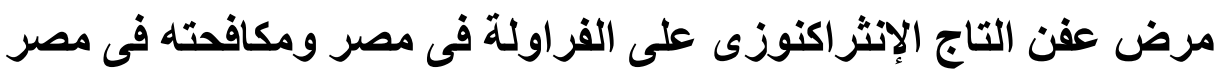

محمد احمد عوض ، محمدى زكى الثنوانى ، محمد عبدالكريم جاد الله قسم النبات الزراعى ـ كلية الزراعة - جامعة المنوفية ـ شبين الكوم ـ مصر التر 


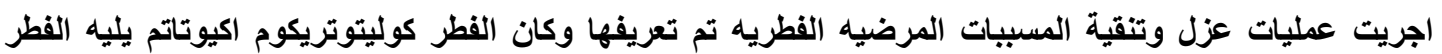

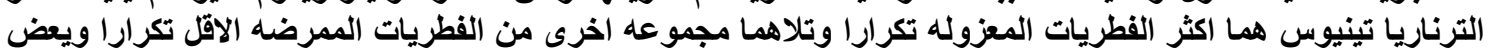

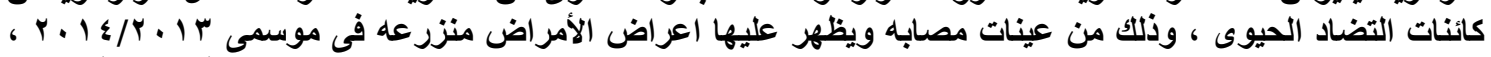

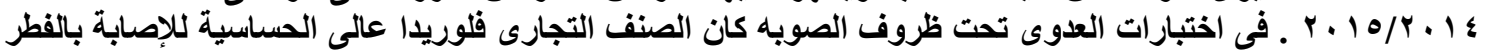

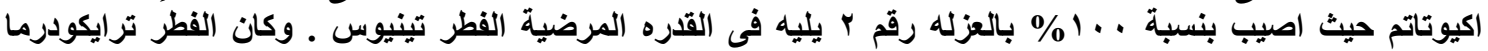

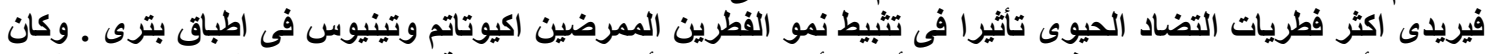

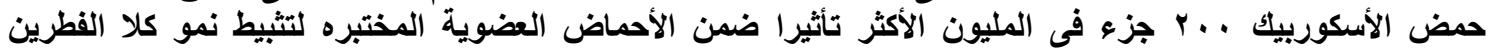

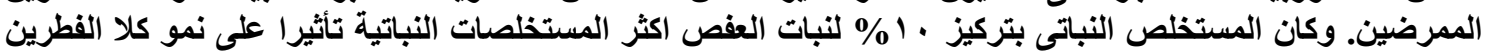

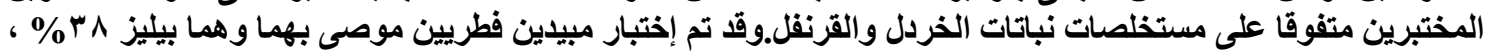

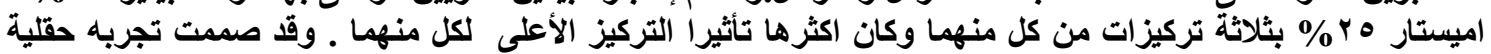

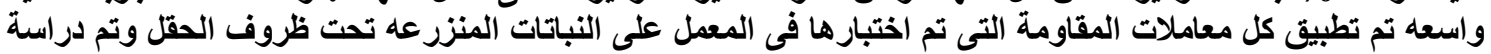

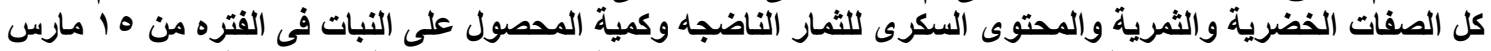

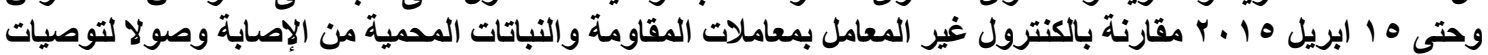

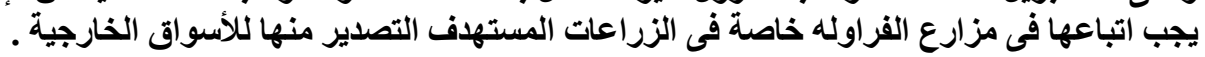

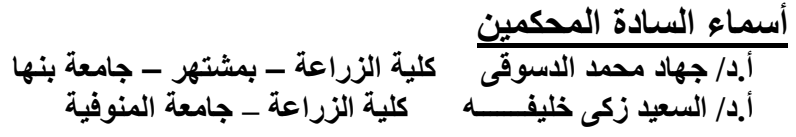


Menoufia J. Plant Prot., Vol. 3 October (2018): 137 - 155 
Table (4): Leaf infection symptoms on strawberry cv. Florida at 3-15 days post trial starting during March 2015.

\begin{tabular}{|c|c|c|c|c|c|c|c|c|c|c|c|c|c|c|c|c|c|c|c|c|}
\hline \multirow{2}{*}{$\begin{array}{l}\begin{array}{l}\text { No. of infected Day } \\
\text { of examination }\end{array} \\
\text { Treatment }\end{array}$} & \multicolumn{4}{|c|}{ Black spot } & \multicolumn{4}{|c|}{ Irregular spot } & \multicolumn{4}{|c|}{ Black Margin } & \multicolumn{4}{|c|}{ Petiol lession } & \multicolumn{4}{|c|}{ Dead leaves } \\
\hline & 3 & 7 & 11 & 15 & 3 & 7 & 11 & 15 & 3 & 7 & 11 & 15 & 3 & 7 & 11 & 15 & 3 & 7 & 11 & 15 \\
\hline Bellis $38 \%$ WG & 0 & 0 & 0 & 0 & 0 & 0 & 0 & 0 & 0 & 0 & 0 & 0 & 0 & 0 & 0 & 0 & 0 & 0 & 0 & 0 \\
\hline Amistar $25 \%$ sc & 0 & 0 & 0 & 0 & 0 & 0 & 0 & 0 & 0 & 0 & 0 & 0 & 0 & 0 & 0 & 0 & 0 & 0 & 0 & 0 \\
\hline Kocide 2000 & 0 & 0 & 0 & 0 & 0 & 0 & 0 & 0 & 0 & 0 & 0 & 1 & 0 & 0 & 0 & 2 & 0 & 0 & 0 & 2 \\
\hline Ascorbic acid 5\% & 0 & 1 & 2 & 2 & 0 & 1 & 2 & 2 & 0 & 0 & 2 & 2 & 0 & 0 & 2 & 2 & 0 & 0 & 0 & 2 \\
\hline Trichoderma viride & 0 & 0 & 0 & 1 & 0 & 0 & 0 & 0 & 0 & 0 & 0 & 0 & 0 & 0 & 0 & 1 & 0 & 0 & 0 & 1 \\
\hline Galls $10 \%$ & 0 & 0 & 0 & 0 & 0 & 0 & 0 & 0 & 0 & 0 & 0 & 0 & 0 & 0 & 0 & 0 & 0 & 0 & 0 & 0 \\
\hline 1/2 Irrigation Water & 0 & 0 & 0 & 1 & 0 & 0 & 0 & 1 & 0 & 0 & 0 & 0 & 0 & 0 & 0 & 1 & 0 & 0 & 0 & 1 \\
\hline 1/2 Fertilization-ratio & 0 & 0 & 1 & 2 & 0 & 0 & 1 & 1 & 0 & 0 & 1 & 1 & 0 & 0 & 0 & 2 & 0 & 0 & 0 & 2 \\
\hline With out mulching & 0 & 0 & 0 & 1 & 0 & 0 & 0 & 1 & 0 & 0 & 0 & 0 & 0 & 0 & 0 & 1 & 0 & 0 & 0 & 0 \\
\hline Potassium citrate & 0 & 0 & 0 & 1 & 0 & 0 & 0 & 1 & 0 & 0 & 0 & 1 & 0 & 0 & 0 & 2 & 0 & 0 & 0 & 2 \\
\hline Control & 0 & 0 & 0 & 0 & 0 & 0 & 0 & 0 & 0 & 0 & 0 & 0 & 0 & 0 & 0 & 0 & 0 & 0 & 0 & 0 \\
\hline Total number & 0 & 1 & 3 & 8 & 0 & 1 & 3 & 6 & 0 & 0 & 3 & 5 & 0 & 0 & 2 & 12 & 0 & 0 & 2 & 10 \\
\hline Control (un-treated) & 0 & 1 & 2 & 2 & 0 & 3 & 4 & 5 & 0 & 1 & 1 & 3 & 0 & 2 & 2 & 4 & 0 & 0 & 2 & 3 \\
\hline
\end{tabular}


Table (5): Characteristics of strawberry flowers cv. Florida variety at 3-15 days from starting trial (from $15^{\text {th }}$ to $30^{\text {th }}$, March 2015 ).

\begin{tabular}{|c|c|c|c|c|c|c|c|c|c|c|c|c|c|c|c|c|c|c|c|c|}
\hline \multirow{2}{*}{$\begin{array}{l}\text { No. of infected Day } \\
\text { of examination }\end{array}$} & \multicolumn{4}{|c|}{ Flower petiol } & \multicolumn{4}{|c|}{ Flower calyx } & \multicolumn{4}{|c|}{ Flower center } & \multicolumn{4}{|c|}{ Flower budes } & \multicolumn{4}{|c|}{ Flower dead } \\
\hline & 3 & 7 & 11 & 15 & 3 & 7 & 11 & 15 & 3 & 7 & 11 & 15 & 3 & 7 & 11 & 15 & 3 & 7 & 11 & 15 \\
\hline Bellis $38 \%$ WG & 0 & 0 & 0 & 0 & 0 & 0 & 0 & 0 & 0 & 0 & 0 & 0 & 0 & 0 & 0 & 0 & 0 & 0 & 0 & 0 \\
\hline Amistar $25 \%$ sc & 0 & 0 & 0 & 0 & 0 & 0 & 0 & 0 & 0 & 0 & 0 & 0 & 0 & 0 & 0 & 0 & 0 & 0 & 0 & 0 \\
\hline Kocide 2000 & 0 & 0 & 1 & 2 & 0 & 0 & 0 & 1 & 0 & 0 & 1 & 2 & 0 & 1 & 2 & 2 & 0 & 0 & 1 & 2 \\
\hline Ascorbic acid 5\% & 0 & 0 & 0 & 5 & 0 & 0 & 0 & 2 & 0 & 3 & 3 & 5 & 0 & 2 & 4 & 5 & 0 & 2 & 3 & 5 \\
\hline Trichoderma viride & 0 & 0 & 1 & 1 & 0 & 0 & 1 & 1 & 0 & 2 & 2 & 3 & 0 & 0 & 4 & 4 & 0 & 0 & 3 & 3 \\
\hline Galls $10 \%$ & 0 & 0 & 0 & 1 & 0 & 0 & 0 & 0 & 0 & 0 & 0 & 1 & 0 & 0 & 0 & 1 & 0 & 0 & 0 & 1 \\
\hline 1/2 Irrigation Water & 0 & 0 & 0 & 1 & 0 & 0 & 0 & 0 & 0 & 0 & 0 & 1 & 0 & 0 & 0 & 1 & 0 & 1 & 2 & 2 \\
\hline $\begin{array}{ll}1 / 2 & \text { Fertilization- } \\
\text { ratio } & \end{array}$ & 0 & 2 & 4 & 4 & 0 & 0 & 0 & 1 & 0 & 2 & 3 & 3 & 0 & 1 & 2 & 4 & 0 & 1 & 4 & 5 \\
\hline With out mulching & 0 & 0 & 0 & 3 & 0 & 0 & 2 & 2 & 0 & 1 & 4 & 4 & 0 & 4 & 5 & 5 & 0 & 3 & 5 & 5 \\
\hline Potassium citrate & 0 & 0 & 0 & 3 & 0 & 0 & 1 & 2 & 0 & 1 & 1 & 5 & 0 & 2 & 3 & 3 & 0 & 1 & 5 & 5 \\
\hline Control & 0 & 0 & 0 & 0 & 0 & 0 & 0 & 0 & 0 & 0 & 0 & 0 & 0 & 0 & 0 & 0 & 0 & 0 & 0 & 0 \\
\hline Total number & 0 & 2 & 3 & 20 & 0 & 0 & 4 & 9 & 0 & 9 & 14 & 24 & 0 & 10 & 20 & 25 & 0 & 8 & 23 & 28 \\
\hline Control (un-treated) & 0 & 1 & 3 & 4 & 0 & 1 & 2 & 3 & 0 & 3 & 4 & 5 & 0 & 3 & 3 & 5 & 0 & 4 & 4 & 5 \\
\hline
\end{tabular}



